Document downloaded from:

http://hdl.handle.net/10251/119853

This paper must be cited as:

Lozano-Torres, B.; Marcos Martínez, MD.; Pardo Vicente, MT.; Sancenón Galarza, F.; Martínez-Máñez, R.; Rurack, K. (2018). Anilinopyridine metal complexes for the selective chromogenic sensing of cyanide anion. Journal of Coordination Chemistry. 71(6):786-796. https://doi.org/10.1080/00958972.2018.1434719

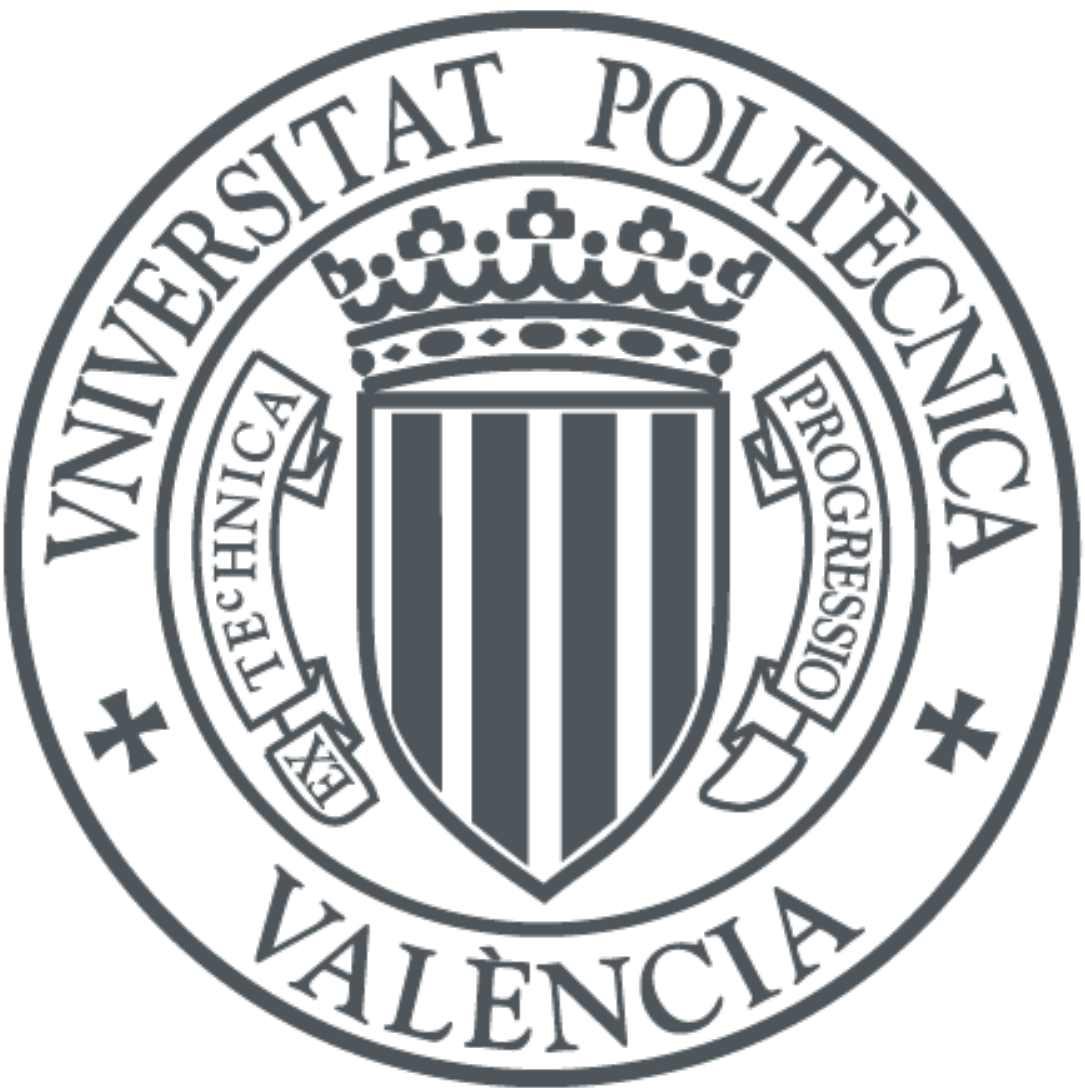

The final publication is available at

http://doi.org/10.1080/00958972.2018.1434719

Copyright Taylor \& Francis

Additional Information 


\section{Anilinopyridine-metal complexes for the selective chromogenic sensing of cyanide anion}

\section{Beatriz Lozano-Torres, M. Dolores Marcos, Teresa Pardo, Félix Sancenón, Ramón Martínez-Máñez \& Knut Rurack}

To cite this article: Beatriz Lozano-Torres, M. Dolores Marcos, Teresa Pardo, Félix Sancenón, Ramón Martínez-Máñez \& Knut Rurack (2018): Anilinopyridine-metal complexes for the selective chromogenic sensing of cyanide anion, Journal of Coordination Chemistry, DOI: 10.1080/00958972.2018.1434719

To link to this article: https://doi.org/10.1080/00958972.2018.1434719

Accepted author version posted online: 30 Jan 2018.

Submit your article to this journal

Q View related articles $₫$

View Crossmark data $\nearrow$ 
Publisher: Taylor \& Francis

Journal: Journal of Coordination Chemistry

DOI: http://doi.org/10.1080/00958972.2018.1434719

\section{Anilinopyridine-metal complexes for the selective chromogenic sensing of cyanide anion}

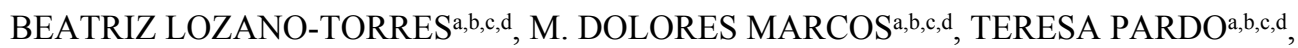
FÉLIX SANCENÓN ${ }^{a, b, c, d,}$, RAMÓN MARTÍNEZ-MÁÑEZ*a,b,c,d and KNUT RURACK ${ }^{\mathrm{e}}$

anstituto Interuniversitario de Investigación de Reconocimiento Molecular y Desarrollo Tecnologico (IDM), Universitat Politècnica de València, Universitat de València. Spain ${ }^{\mathrm{b}}$ CIBER de Bioingeniería, Biomateriales y Nanomedicina (CIBER-BBN), Spain

'Unidad Mixta de Investigación en Nanomedicina y Sensores. Universitat Politècnica de València, Instituto de Investigación Sanitaria La Fe, Valencia, Spain

dUnidad Mixta UPV-CIPF de Investigación en Mecanismos de Enfermedades y Nanomedicina, Valencia,

Universitat Politècnica de València, Centro de Investigación Príncipe Felipe, Valencia Spain

${ }^{\mathrm{e}}$ Chemical and Optical Sensing Division, Bundesanstalt für Materialforschung und -prüfung (BAM),

Richard-Willstätter-Strasse 11, 12489 Berlin, Germany

Probe 1, which contains an anilinopyridine chromophore and an aza-oxa macrocyclic subunit, presented an absorption band centered at $340 \mathrm{~nm}$ in acetonitrile. Addition of $\mathrm{Fe}(\mathrm{III}), \mathrm{Cr}$ (III) and $\mathrm{Hg}$ (II) induced growth of a new absorption band centered at $c a .430 \mathrm{~nm}$ (with a concomitant color change from colorless to yellow), whereas in the presence of $\mathrm{Cu}(\mathrm{II}), \mathrm{Zn}(\mathrm{II})$ and $\mathrm{Pb}$ (II) less marked changes were observed. The prominent color changes observed upon addition of $\mathrm{Fe}(\mathrm{III})$, $\mathrm{Cr}(\mathrm{III})$ and $\mathrm{Hg}$ (II) were ascribed to the formation of 1:1 stoichiometry complexes with probe 1 . Coordination of $\mathrm{Fe}(\mathrm{III}), \mathrm{Cr}(\mathrm{III})$ and $\mathrm{Hg}(\mathrm{II})$ with the pyridine fragment of $\mathbf{1}$ induced an enhancement of the charge transfer character accompanied with a marked bathochromic shift that was reflected in a color change from colorless to yellow. The strength of the interaction between probe 1 and Fe(III) cation was modulated upon interaction with selected anions. Moreover, of all the anions tested, only cyanide was able to induce the bleaching of the yellow $\mathbf{1} \cdot \mathrm{Fe}(\mathrm{III})$ complex solution. This bleaching was ascribed to the formation of $\mathbf{1} \cdot \mathrm{Fe}(\mathrm{III})-\mathrm{CN}$ complex that restored, to some extent, the optical features of the free probe allowing the chromogenic sensing of cyanide; 1. Fe(III) complex was used to detect cyanide in acetonitrile-water 90:10 v/v mixtures with good recoveries (in the $73-90 \%$ range).

*Corresponding author. Email: rmaez@qim.upv.es 
Keywords: Anilinopyridine; Charge-transfer; Fe(III) Complex; Chromogenic; Cyanide

Anions play vital roles in biological systems but abnormal concentrations can cause several diseases [1]. Inside the vast realm of anions, cyanide is one of the most toxic and dangerous for the environment [2]. Concentrations of this anion in the $0.5-3.5 \mathrm{mg} / \mathrm{kg}$ body weight interval are lethal to humans. At these concentrations, cyanide strongly binds to the cytochrome $\mathrm{c}$ active sites resulting in inhibition of oxygen transport and cellular respiration with subsequent central nervous system damage [3]. However, despite its toxicity, cyanide is extensively used in the chemical industry. For instance, cyanide derivatives are used in metal mining processes (isolation of gold and silver from its ores), organic chemical industries (fabrication of nylon and other synthetic fibers and resins), wastewater treatment facilities and iron and steel plants. All these industries can potentially be sources of water contamination with eyanide. The World Health Organization (WHO) established a permissive concentration of cyanide in drinking water of $1.9 \mu \mathrm{M}$ while in industrial effluents this level is fixed below $1 \mu \mathrm{M}$ [4].

Taking into account the above mentioned facts, easy and affordable detection methods for cyanide are of interest. Currently, cyanide detection is achieved using colorimetric, titrimetic and electrochemical methods [5]. Among them, chromo-fluorogenic protocols for the detection of cyanide has attracted attention due to the high degree of selectivity usually achieved and the use of common and simple instrumentation or the visual detection to the naked eye [6]. In fact chromo-fluorogenic protocols are not time consuming and do not require trained personnel. Traditionally, chromo-fluorogenic sensors for anions have been developed using the "binding site-signaling unit" paradigm. In this approach a binding site, designed by taking into account the chemical features of the guest in order to achieve a high complementarity degree, is covalently linked with a signaling unit that is expected to transform the coordination event into an easily measurable optical macroscopic signal [7]. Another approach, developed by Anslyn and coworkers, is the use of a competition assay between a chromophore bounded to a receptor and a certain anion [8]. In a first step a sensing ensemble between a synthetic receptor and a dye/fluorophore was formed. In the presence of a target anion its coordination with the synthetic receptor displaced the dye/fluorophore to the solution. If the optical properties of the dye/fluorophore alone are different to that presented in the sensing ensemble an output signal is 
observed. Finally, the use of anion-induced chemical reactions coupled with color and/or emission changes have been extensively explored (chemodosimeter approach) [9].

Here we report the synthesis and chromogenic behavior of probe $\mathbf{1}$ that contains an aza-oxa macrocycle embedded in an anilinopyridine conjugated chromophore [10]. This chemosensor forms colored complexes with several metal cations that were characterized by the presence of a charge transfer band in the visible zone. Moreover, the 1. $\mathrm{Fe}(\mathrm{III})$ complex is able to detect $\mathrm{CN}^{-}$; only the presence of cyanide induced a clear color change from yellow to colorless allowing the "naked eye" detection of this dangerous anion.

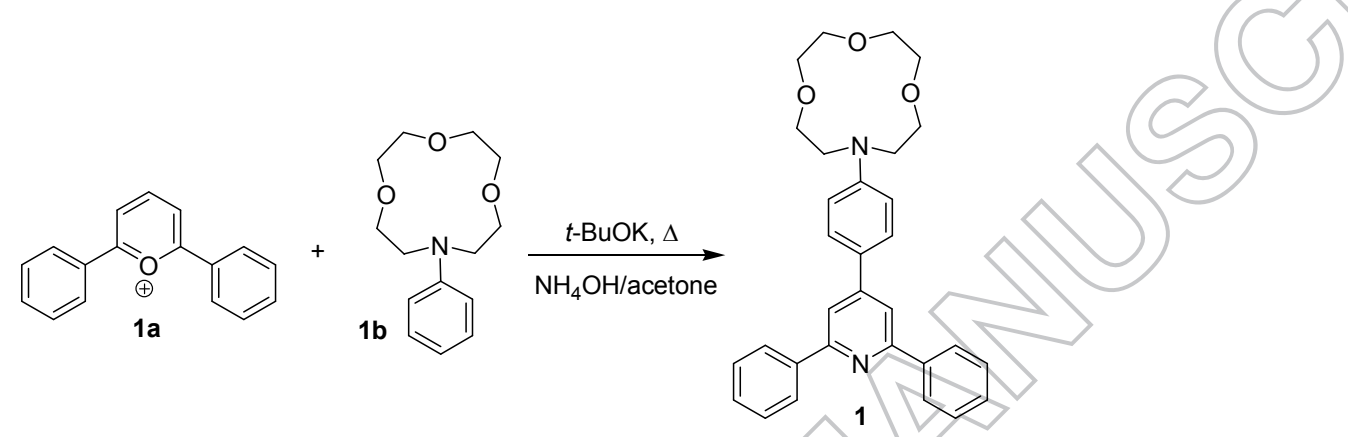

Scheme 1. Synthesis and structure of chemosensor 1 .

The synthesis of probe $\mathbf{1}$ was previously published [11]. However we used here a slightly modified procedure in order to enhance the yields for the preparation of $\mathbf{1 b}$ and $\mathbf{1}$. Briefly, an electrophilic aromatic substitution of 2,6-diphenylpyrylium perchlorate (1a) with 10-phenyl-10aza-1,4,7-trioxacyclododecane (1b) in DMF at $150^{\circ} \mathrm{C}$ was used to obtain $\mathbf{1}$. Subsequent treatment with ammonium hydroxide and column chromatography with aluminum oxide afforded the desired receptor in 70\% yield as a pallid yellow solid (see scheme 1). ${ }^{1} \mathrm{H}$ and ${ }^{13} \mathrm{C}$ NMR, mass spectra and elemental analyses were in accord with the proposed formulation.

The chemical structure of $\mathbf{1}$ consists of a chromophore composed of an aniline donor unit (D) and a pyridine acceptor moiety (A) endowing charge transfer character to the probe [12]. Moreover, 1 contains two nitrogens with potential metal cation coordination ability. One nitrogen is located in the 2,6-diphenylpyridine subunit and the other in the aniline group. In spite of the fact that simple aniline derivatives weakly coordinate certain transition metal cations, the donor site of probe $\mathbf{1}$ was additionally functionalized with a small aza trioxa macrocycle as 
"shielding group" [10]. This modification inhibits interaction with the aniline donor group and led to preferential coordination of metal cations with the pyridine unit (vide infra).

Acetonitrile solutions of probe $1\left(9.0 \times 10^{-5} \mathrm{M}\right)$ show an absorption band centered at $343 \mathrm{~nm}$ with charge transfer features (see figure 1a). In fact, certain solvatochromism was observed for the probe. The absorption band of 1 was found at 333, 337 and $343 \mathrm{~nm}$ in hexane, diethyl ether and acetonitrile, respectively [11]. Figure $1 \mathrm{~b}$ shows the color changes observed upon addition of one eq. of selected metal cations (Fe(III), $\mathrm{Cr}$ (III), Ni(II), $\mathrm{Zn}$ (II), Cu(II), $\mathrm{Cd}$ (II), $\mathrm{Hg}(\mathrm{II})$ and $\mathrm{Pb}(\mathrm{II}))$ to acetonitrile solutions of probe 1 . As could be seen, addition of $\mathrm{Fe}(\mathrm{III})$, $\mathrm{Cr}(\mathrm{III})$ and $\mathrm{Hg}(\mathrm{II})$ induced a bright yellow color due to the growth of a new absorption band centered at $c a .440 \mathrm{~nm}$ with molar absorptivities of 22450, 22110 and $21440 \mathrm{M}^{-1} \mathrm{~cm}^{-1}$ for Fe(III), $\mathrm{Cr}(\mathrm{III})$ and $\mathrm{Hg}(\mathrm{II})$, respectively (see figure 1a). Other metal cations such as $\mathrm{Cu}(\mathrm{II}), \mathrm{Zn}$ (II) and $\mathrm{Pb}$ (II) changed the color of the solution to pale yellow, whereas $\mathrm{Ni}(\mathrm{II})$ and $\mathrm{Cd}(\mathrm{II})$ did not induce any noticeable color change (see also figure $1 \mathrm{~b}$ ). The color changes observed and the remarkable bathochromic shift of the absorption band, upon addition of $\mathrm{Fe}(\mathrm{III}), \mathrm{Cr}(\mathrm{III})$ and $\mathrm{Hg}$ (II), were ascribed to a preferential coordination of these metal cations with the 2,6-diphenylpyridine acceptor subunit of probe $\mathbf{1}$. This coordination induced an increase in the charge transfer character of the band due to the higher electron deficiency of the pyridine acceptor subunit in the formed complexes. The pale yellow color observed in the presence of $\mathrm{Cu}(\mathrm{II}), \mathrm{Zn}(\mathrm{II})$ and $\mathrm{Pb}$ (II) indicated less affinity of these cations to probe $\mathbf{1}$. Titration experiments of 1 with $\mathrm{Fe}(\mathrm{III}), \mathrm{Hg}(\mathrm{II})$, $\mathrm{Cu}(\mathrm{II}), \mathrm{Zn}(\mathrm{II})$ and $\mathrm{Pb}(\mathrm{II})$ clearly indicated the formation of 1:1 probe-metal stoichiometry complexes. From the titration data the $\log \mathrm{K}$ values for the complex formation of probe $\mathbf{1}$ with the corresponding cations were calculated and are shown in table 1 . The obtained $\log \mathrm{K}$ values are similar to that found in the literature for other pyridine derivatives with transition metal cations [13].

Interference studies of the response of probe 1 toward $\mathrm{Fe}(\mathrm{III}), \mathrm{Hg}(\mathrm{II})$ and $\mathrm{Cr}(\mathrm{III})$ in the presence of the other selected cations was tested. The obtained results in the presence of one eq. of $\mathrm{Ni}$ (II) and $\mathrm{Cd}(\mathrm{II})$ are shown in figure 2 . As could be seen, $\mathrm{Ni}(\mathrm{II})$ and $\mathrm{Cd}(\mathrm{II})$ were unable to modify the chromogenic response of probe 1 in the presence of $\mathrm{Fe}(\mathrm{III}), \mathrm{Hg}$ (II) and $\mathrm{Cr}$ (III) cations.

In a second step, the ability to chromogenically detect anions using the $1 \cdot \mathrm{M}^{\mathrm{tn}}$ complexes as probes was tested. For this purpose, potential color changes of acetonitrile solutions of $\mathbf{1} \cdot \mathrm{M}^{+\mathrm{n}}$ 
complexes $\left(9.0 \times 10^{-5} \mathrm{M}\right)$ were studied in the presence of selected anions (i.e. fluoride, chloride, bromide, iodide, acetate, benzoate, cyanide, nitrate, dihydrogenphosphate and hydrogensulfate). Complexes $\mathbf{1} \cdot \mathrm{Cu}(\mathrm{II}), \mathbf{1} \cdot \mathrm{Pb}(\mathrm{II})$ and $\mathbf{1} \cdot \mathrm{Zn}(\mathrm{II})$ presented low levels of selectivity (data not shown). For instance yellow solutions of $\mathbf{1} \cdot \mathrm{Cu}$ (II) turned colorless in the presence of fluoride, acetate, cyanide and dihydrogenphosphate. Moreover, yellow acetonitrile solutions of $\mathbf{1} \cdot \mathrm{Pb}(\mathrm{II})$ and $\mathbf{1} \cdot \mathrm{Zn}(\mathrm{II})$ became colorless with fluoride, chloride, acetate, benzoate, cyanide, dihydrogenphosphate and hydrogensulfate. In contrast, a more selective response was obtained with $\mathbf{1} \cdot \mathrm{Hg}(\mathrm{II})$ and $\mathbf{1} \cdot \mathrm{Fe}(\mathrm{III})$ complexes. Figure 3 shows the UV-vis spectra and the color changes observed upon addition of selected anions to acetonitrile solutions of $1 \cdot \mathrm{Fe}(\mathrm{III})\left(9.0 \times 10^{-5} \mathrm{M}\right)$. Of all the anions tested, only cyanide was able to induce a nearly complete disappearance of the charge-transfer band of the $\mathbf{1} \cdot \mathrm{Fe}(\mathrm{III})$ complex (figure $3 \mathrm{a}$ ). This fact was reflected in a complete bleaching of the yellow $\mathbf{1} \cdot \mathrm{Fe}(\mathrm{III})$ complex solution (figure $3 \mathrm{~b}$ ). A similar behavior, in terms of UV-visible and color changes, was observed for the $\mathbf{1} \cdot \mathrm{Hg}(\mathrm{II})$ complex in the presence of selected anions. Titration experiments of acetonitrile solutions of $1 \cdot \mathrm{Fe}(\mathrm{HI})$ with cyanide showed the formation of 1:1 stoichiometry adducts. $\mathrm{Log} \mathrm{K}$ yalue for the $1 \cdot \mathrm{Fe}(\mathrm{III}) \cdot \mathrm{CN}^{-}$adduct formation, calculated through nonlinear least-squares treatment of the titration profile, was $6.6 \pm 0.2$.

In order to understand the chromogenic behavior observed in the presence of cyanide with $\mathbf{1} \cdot \mathrm{Hg}(\mathrm{II})$ and $\mathbf{1} \cdot \mathrm{Fe}(\mathrm{III})$ complexes, ${ }^{1} \mathrm{H}$ NMR studies were performed. ${ }^{1} \mathrm{H}$ NMR in the presence of $\mathrm{Fe}$ (III) cannot be carried out due to the paramagnetic character of the iron cation, but a similar coordination behavior with cyanide to that shown by $\mathrm{Hg}$ (II) complex was expected to occur. ${ }^{1} \mathrm{H}$ NMR studies on the $1 \cdot H g($ II) system clearly showed that metal cation coordinated with the 2,6-diphenylpyridine acceptor moiety. At this respect, the singlet of the pyridine protons centered at $7.72 \mathrm{ppm}$ was shifted downfield to $7.85 \mathrm{ppm}$ whereas the ortho protons of the monosubstituted benzene rings were shifted upfield from 8.16 to $7.90 \mathrm{ppm}$. Besides the other protons of the monosubstituted benzene were shifted by $+0.10 \mathrm{ppm}$. The observed changes together with the fact that macrocycle protons suffers negligible shifts (between 0.01 and $0.03 \mathrm{ppm}$ ) pointed to a preferential coordination of $\mathrm{Hg}(\mathrm{II})$ cation with the pyridine ring. Upon addition of cyanide, the ${ }^{1} \mathrm{H}$ NMR of $\mathbf{1}$ is not completely retrieved, suggesting that cyanide coordinates with the cation, forming a ternary molecular adduct, without completely removing $\mathrm{Hg}(\mathrm{II})$ from the pyridine heterocycle [11]. Coordination of cyanide with the metal bounded with probe 1 diminished the strength of the cation-pyridine interaction with subsequent reduction of 
the charge transfer character in the final adduct (see scheme 2). This reduction in the charge transfer character was the responsibility of the hypsochromic shift observed upon cyanide addition to solutions of $\mathbf{1} \cdot \mathrm{Hg}(\mathrm{II})$ and $\mathbf{1} \cdot \mathrm{Fe}(\mathrm{III})$ complexes.

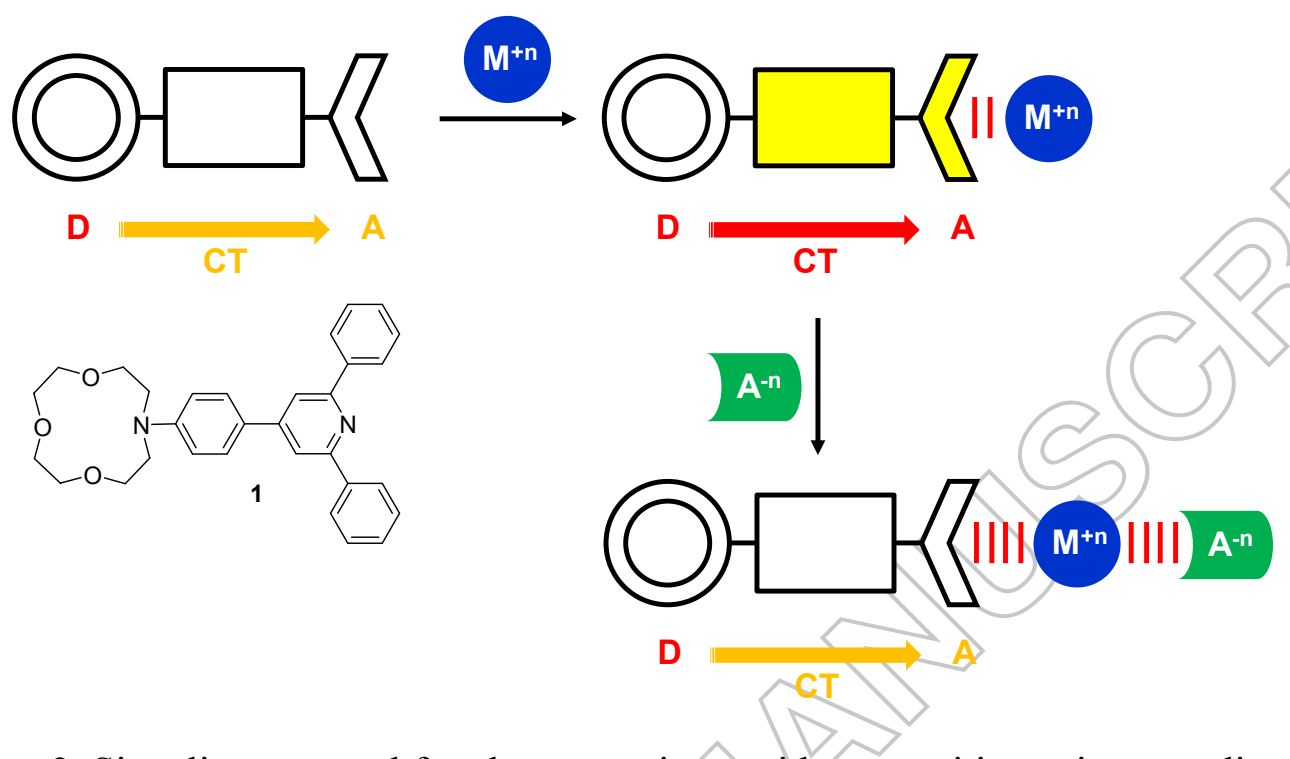

Scheme 2. Signaling protocol for chromogenic cyanide recognition using coordinative complexes of probe $\mathbf{1}$ with metal cations. D is the donor part of the probe (aniline) whereas A designed the acceptor region (pyridine). CT indicated the charge transfer nature of the electronic transition in the free probe and in the complexes. The strength of the CT is indicated by a colored arrow (orange for a weak CT and red for a stronger CT).

Finally, in order to test the potential utility of $\mathbf{1} \cdot \mathrm{Fe}(\mathrm{III})$ complex for the selective detection of cyanide in water further experiments were carried out [14]. Although the above described selective chromogenic behavior was not perceived in pure water it was still observed in acetonitrile-water $90: 10 \mathrm{v} / \mathrm{v}$ mixtures. Therefore we used calibration curves for cyanide in acetonitrile-water 90:10 v/v solutions (see figure 4) for cyanide determination in water. From figure 4 a limit of detection for cyanide in acetonitrile-water 90:10 v/v solutions was calculated to be $3.16 \times 10^{-5} \mathrm{M}$. The limit of detection concurs with the inflection point of the two slopes observed for the concentration range studied. In a typical experiment for the detection of cyanide, $0.5 \mathrm{~mL}$ of water containing a certain amount of cyanide was mixed with $4.5 \mathrm{~mL}$ of an acetonitrile solution containing the $\mathbf{1} \cdot \mathrm{Fe}$ (III) complex. Cyanide solution in water also contained other typically water-present anions (chloride, nitrate, sulfate, sodium and potassium in 
concentration ranges $1.0 \times 10^{-4}-8.0 \times 10^{-4} \mathrm{M}$ ). Using the calibration curve shown in figure 4 the concentration of cyanide was determined quite accurately in different water samples (see table 2) with recoveries in the $73-90 \%$ range.

In summary, we have shown herein the synthesis and characterization of new chromogenic cyanide sensors based on $\mathrm{Fe}(\mathrm{III})$ and $\mathrm{Hg}(\mathrm{II})$ complexes of an anilinopyridinecontaining derivative (1). The method uses a colorless probe that is switched ON (yellow color) in the presence of certain metal cations. This produces the colored $\mathbf{1} \cdot \mathrm{Fe}(\mathrm{III})$ and $\mathbf{1} \cdot \mathrm{Hg}(\mathrm{II})$ complexes that are selectively bleached (switched OFF) by the cyanide anion. Further studies will be carried out to determine the applicability of this simple method for the determination of cyanide in a large range of locations.

\section{Experimental}

\section{Materials and methods}

Commercially available reagents were used without purification. Air/water-sensitive reactions were performed in flame-dried glassware under argon. Acetonitrile was dried with $\mathrm{CaH}_{2}$ and distilled prior to use. Perchlorate salts of $\mathrm{Cr}(\mathrm{III}), \mathrm{Pb}(\mathrm{II}), \mathrm{Fe}(\mathrm{III}), \mathrm{Ni}(\mathrm{II})$, and $\mathrm{Cd}(\mathrm{II})$ and triflate salts of $\mathrm{Hg}(\mathrm{II})$ and $\mathrm{Zn}(\mathrm{II})$ were purchased from Aldrich, whereas the triflate salt of $\mathrm{Cu}$ (II) was

purchased from Acros. The selected anions (fluoride, chloride, bromide, iodide, acetate, benzoate, cyanide, nitrate, dihydrogenphosphate and hydrogensulfate) were used as tetrabutylammonium salts and were purchased from Aldrich. UV-visible spectra were recorded with a JASCO V-650 spectrophotometer. ${ }^{1} \mathrm{H}$ and ${ }^{13} \mathrm{C}$-NMR spectra were acquired in a BRUKER AVANCE III (400 MHZ), where mass spectra were carried out in a TRIPLETOF T5600 (ABSciex, USA) spectrometer.

\section{Synthesis of 10-phenyl-10-aza-1,4,7-trioxacyclododecane (1b)}

In a typical procedure $N, N$-phenyldiethanolamine $(1 \mathrm{~g}, 5.5 \mathrm{mmol})$ was dissolved in anhydrous acetonitrile $(100 \mathrm{~mL})$ in an inert atmosphere $(\mathrm{Ar})$. Then, potassium tert-butoxide $(1.54 \mathrm{~g}$, $13.7 \mathrm{mmol}$ ) was added at room temperature in small portions during $180 \mathrm{~min}$. Afterward the crude solution was heated to reflux and 3-oxapentane-1,5-dimethanesulfonate (1.44 g, $5.5 \mathrm{mmol})$ was slowly added during $10 \mathrm{~h}$. The reaction was refluxed overnight. The crude was filtered off and concentrated in a rotary evaporator to give an orange oil. This oil was then purified through 
column chromatography using aluminium oxide and dichloromethane as eluent to give 10-phenyl-10-aza-1,4,7-trioxacyclododecane (1b) as a pale yellow oil $(0.83 \mathrm{~g}, 3.3 \mathrm{mmol}, 60 \%$ yield). ${ }^{1} \mathrm{H}$ NMR (400 MHz, $\mathrm{CDCl}_{3}$ ) $\delta 3.55(\mathrm{t}, 4 \mathrm{H}), 3.64(\mathrm{~m}, 8 \mathrm{H}), 3.83(\mathrm{t}, 4 \mathrm{H}), 6.68(\mathrm{t}, 2 \mathrm{H}), 6.70$ $(\mathrm{d}, 1 \mathrm{H}), 7.18(\mathrm{t}, 2 \mathrm{H}) .{ }^{13} \mathrm{C} \mathrm{NMR}\left(101 \mathrm{MHz}, \mathrm{CDCl}_{3}\right) \delta$ 52.4, 69.6, 69.8, 71.5, 112.2, 116.0, 129.0, 148.4. HRMS-EI m/z: calcd for $\mathrm{C}_{14} \mathrm{H}_{21} \mathrm{NO}_{5} 251.1521$; found: $252.1603\left(\mathrm{M}+\mathrm{H}^{+}\right)$.

\section{Synthesis of probe 1}

10-Phenyl-10-aza-1,4,7-trioxacyclododecane (1b, $350 \mathrm{mg}, 1.39 \mathrm{mmols})$ and 2,6-diphenylpyrylium perchlorate (1a, $925 \mathrm{mg}, 2.78 \mathrm{mmols})$ were dissolved in anhydrous dimethylformamide $(15 \mathrm{~mL})$ and heated at $150^{\circ} \mathrm{C}$ for six hours. Then, and at room temperature, diethyl ether $(60 \mathrm{~mL})$ was added and the crude reaction was stirred overnight. A magenta oil precipitate was separated by decantation. This magenta oil was dissolved in dry acetone and excess of ammonium hydroxide were added. The crude was concentrated in a rotary evaporator and then purified through column chromatography using dichloromethane-hexane $1: 1 \mathrm{v} / \mathrm{v}$ as eluent. Probe 1 was obtained as pale yellow solid ( $468 \mathrm{mg}, 0.97 \mathrm{mmol}, 70 \%$ yield). ${ }^{1} \mathrm{H}$ NMR $\left(400 \mathrm{MHz}, \mathrm{CDCl}_{3}\right) \delta 3.62(\mathrm{~m}, 12 \mathrm{H}), 3.90(\mathrm{t}, 4 \mathrm{H}), 6.84(\mathrm{~d}, 2 \mathrm{H}), 7.41(\mathrm{t}, 3 \mathrm{H}), 7.47(\mathrm{t}, 3 \mathrm{H}), 7.63(\mathrm{~d}$, 2H), $7.72(\mathrm{~s}, 2 \mathrm{H}), 8.16(\mathrm{~d}, 4 \mathrm{H}) .{ }^{13} \mathrm{C} \mathrm{NMR}\left(101 \mathrm{MHz}, \mathrm{CDCl}_{3}\right) \delta$ 53.1, 70.1, 70.5, 72.1, 113.2, $116.5,127.7,128.4,129.2,129.4,140.6,150.0,150.4,157.9$. HRMS-EI m/z: calcd for $\mathrm{C}_{31} \mathrm{H}_{32} \mathrm{~N}_{2} \mathrm{O}_{3} 480.2413$; found: $481.2489\left(\mathrm{M}+\mathrm{H}^{+}\right)$.

\section{Stability constants of selected metal ion complexes of 1}

The intensity of the $440 \mathrm{~nm}$ band of $9.0 \times 10^{-5} \mathrm{M}$ solutions of $\mathbf{1}$ in acetonitrile was monitored during a titration withincreasing amounts of the metal ions $\mathrm{Fe}$ (III), $\mathrm{Hg}$ (II), $\mathrm{Cu}$ (II), $\mathrm{Zn}$ (II) and $\mathrm{Pb}$ (II), which allowed us to determine the complex stability constants. In these three cases, the formation of 1:1 ligand-to-metal complexes was found and the calculated $\log K$ values, through nonlinear least-squares fitting of the titration profiles, are provided in table 1.

\section{Interaction of 1 with metal cations}

The interaction of $\mathbf{1}$ with certain cations was studied by UV-Vis spectrophotometry. Receptor $\mathbf{1}$ consists of an anilino-type donor moiety attached through a single bond to a 2,6-diphenylpyridine acceptor group, exhibiting $\pi$ electron delocalization over the entire 
chomogenic system. As a consequence, 1 shows an intramolecular charge transfer band, typical for such donor-acceptor-substituted dyes, centered at $340 \mathrm{~nm}$ in acetonitrile. Upon addition of different metal cations to $\mathbf{1}$ in acetonitrile, three different behaviors were observed.

- The addition of the metal cations $\mathrm{Fe}(\mathrm{III}), \mathrm{Cr}(\mathrm{III})$ and $\mathrm{Hg}(\mathrm{II})$ induced the development of a new band at $c a .430 \mathrm{~nm}$ with the corresponding change of the solution from colorless to yellow. This bathochromic shift of the charge transfer band is consistent with a coordination-induced increase in the acceptor strength of the pyridine unit and thus attributed to coordination of the metal ions to the pyridine group. Less marked color changes were observed upon addition of $\mathrm{Cu}(\mathrm{II}), \mathrm{Zn}(\mathrm{II})$ and $\mathrm{Pb}(\mathrm{II})$, indicating a weaker affinity of these cations for probe 1 .

- Several other first row transition metal cations, such as $\mathrm{Ni}$ (II) and Cd(II), are unable to change the UV-Vis spectral profile of receptor 1 distinctly at micromolar concentrations, suggesting that no coordination takes place.

\section{Cyanide detection using $1 \cdot \mathrm{Fe}(\mathrm{III})$ complex}

In a typical experiment $0.5 \mathrm{~mL}$ of water containing cyanide $(0.80,2.35$ and $3.54 \mathrm{ppm})$ was mixed with $4.5 \mathrm{~mL}$ of an acetonitrile solution containing the $1 \cdot \mathrm{Fe}(\mathrm{III})$ complex. Cyanide solution in water also contained other typically water-present anions (chloride, nitrate, sulfate, sodium and potassium in concentration ranges $\left.1.0 \times 10^{-4}-8.0 \times 10^{-4} \mathrm{M}\right)$. Then, the absorbance of the resulting mixture was measured and the concentration of cyanide measured using the calibration curve shown in figure 3. Cyanide was determined quite accurately in the different water samples with recoveries in the $73-90 \%$ range.

\section{Acknowledgements}

The authors thank the Spanish Government (projects MAT2015-64139-C4-1-R and AGL201570235-C2-2-R (MINECO/FEDER)) and the Generalitat Valenciana (project PROMETEOII/2014/047) for support.

\section{References}

[1] G.D. Muir, Hazards in Chemical Laboratory, The Royal Chemical Society, London (1997). 
[2] (a) R. Gracia, G. Shepherd. Pharmacotherapy, 24, 1358 (2004). (b) D.W. Boening, C.M. Chew. Water Air Sol. Pollut., 109, 67 (1999).

[3] (a) Y. Chen, L.J. Deterding, K.B. Tomer, R.P. Mason. Biochemistry, 39, 4415 (2000).

(b) T. Tylleskar, W.P. Howlett, H.T. Rwiza, S. Aquilonius, E. Stalberg, B. Linden, A. Mandahl, H.C. Larsen, G.R. Brubaker, H. Rosling. J. Neurol. Neurosurg. Psychiatry, 56, 638 (1993).

[4] (a) WHO, Guidelines for drinking-water quality, World Health Organisation, Geneva, Switzerland (2011), p. 342. (b) E. Gail, S. Gos, R. Kulzer, J. Lorosch, A. Rubo, M. Sauer, R. Kellens, J. Reddy, N. Steier, W. Hasenpusch, Cyano Compounds, Inorganic, in Ullmann's Encyclopedia of industrial Chemistry, Wiley VCH, New York (2011).

[5] (a) Standard Methods for the Examination of Water and Wastewater, 22nd Edition, American Public Health Association, Washington DC, USA (2012). (b) T. Suzuki, A. Hioki, M. Kurahashi. Anal. Chim. Acta, 476, 159 (2003). (c) A. Safavi, N. Maleki, H.R. Shahbaazi. Anal. Chim. Acta, 503, 213 (2004). (d) V.K. Rao, S.R. Suresh, N.B.S.N. Rao, P. Rajaram. Bull. Electrochem., 13, 327 (1997).

[6] (a) Z. Xu, X. Chen, H.N. Kim, J. Yoon. Chem. Soc. Rev., 39, 127 (2010). (b) F. Wang, L. Wang, X. Chen, J. Yoon. Chem. Soc. Rev., 43, 4312 (2014). (c) W.C. Lin, S.K. Fang, J.W. Hu, H.Y. Tsai, K.Y. Chen. Anal. Chem., 86, 4648 (2014). (d) L. Wang, L. Zhu, D. Cao. New J. Chem., 39,7211 (2015). (e) P. Singh, L.S. Mittal, S. Kumar, G. Bhargava, S. Kumar. J. Fluoresc,, 24, 909 (2014). (f) K. Hong, H. Yoon, W. Jang. Chem. Commun., 51, 7486 (2015). (g) R.M.F. Batista, E. Oliveira, S.P.G. Costa, C. Lodeiro, M.M.M. Raposo. Supramol. Chem., 26, 71 (2014). (h) P.A. Gale, C. Caltagirone. Chem. Soc. Rev., 44, 4212 (2015). (i) Y, Shiraishi, M. Nakamura, T. Kogurea, T. Hirai. New J. Chem., 40, 1237 (2016). (j) K.S. Bejoymohandas, A. Kumar, S. Sreenadh, E. Varathan, S. Varughese, V. Subramanian, M.L.P. Reddy. Inorg. Chem., 55, 3448 (2016). (k) S. El Sayed, M. Licchelli, R. Martínez-Máñez, F. Sancenón. Chem. Asian J., 12, 2670 (2017).

[7] (a) R. Martínez-Máñez, F. Sancenón. Chem. Rev., 103, 4419 (2003). (b) M.E. Moragues, R. Martínez-Máñez, F. Sancenón. Chem. Soc. Rev., 40, 2593 (2011). (c) L.E. SantosFigueroa, M.E. Moragues, E. Climent, A. Agostini, R. Martínez-Máñez, F. Sancenón. Chem. Soc. Rev., 42, 3489 (2013). 
[8] (a) S.L. Wiskur, H. Ait-Haddou, J.J. Lavigne, E.V. Anslyn. Acc. Chem. Res., 34, 963 (2001). (b) B.T. Nguyen, E.V. Anslyn. Coord. Chem. Rev., 250, 3118 (2006).

[9] (a) J. Du, M. Hu, J. Fan, X. Peng. Chem. Soc. Rev., 41, 4511 (2012). (b) K. Kaur, R. Saini, A. Kumar, V. Luxami, N. Kaur, P. Singh, S. Kumar. Coord. Chem. Rev., 256, 1992 (2012).

[10] B. García-Acosta, X. Albiach-Martí, E. García, L. Gil, R. Martínez-Máñez, K. Rurack, F. Sancenón, J. Soto. Chem. Commun., 774 (2004).

[11] B. García-Acosta, R. Martínez-Máñez, F. Sancenón, J. Soto, K. Rurack, M. Spieles, E. García-Breijo, L. Gil. Inorg. Chem., 46, 3123 (2007).

[12] (a) J. Chen, W. Liu, J. Ma, H. Xu, J. Wu, X. Tang, Z. Fan, P. Wang. J. Org. Chem., 77, 3475 (2012). (b) J.W. Verhoeven. Top. Fluoresc. Spectrosc.,9, 249 (2005). (c) K. Rurack. Spectrochim. Acta, Part A, 57, 2161 (2001).

[13] (a) M. Kurihara, T. Kawashima, K. Osutzumi. Z. Naturforsch. B, 55, 277 (2000).

(b) D.A. Thornton. Coord. Chem. Rev., 104, 251 (1990).

[14] Z. Xu, X. Chen, H.N. Kim, J. Yoon. Chem. Soc. Rev., 39, 127 (2010).

Table 1. Values of the logarithm of the stability constant for formation of metal complexes with probe 1. Values in parentheses are standard deviation of the last digit.

\begin{tabular}{|c|c|c|c|c|}
\hline $\mathrm{Fe}(\mathrm{III})$ & $\mathrm{Hg}(\mathrm{II})$ & $\mathrm{Cu}(\mathrm{II})$ & $\mathrm{Zn}(\mathrm{II})$ & $\mathrm{Pb}(\mathrm{II})$ \\
\hline $6.90(2)$ & $5.11(1)$ & $6.40(2)$ & $4.30(1)$ & $3.81(1)$ \\
\hline
\end{tabular}


Table 2. Concentration of cyanide (in ppm) in different samples of water. Concentration of cyanide was determined using the calibration curve in figure 3.

\begin{tabular}{lll}
\hline Real concentration $(\mathrm{ppm})$ & Determined using 1·Fe(III) $(\mathrm{ppm})$ & Recovery $(\%)$ \\
\hline 0.80 & 0.72 & 90 \\
2.35 & 1.72 & 73 \\
3.54 & 2.83 & 80 \\
\hline
\end{tabular}

a)

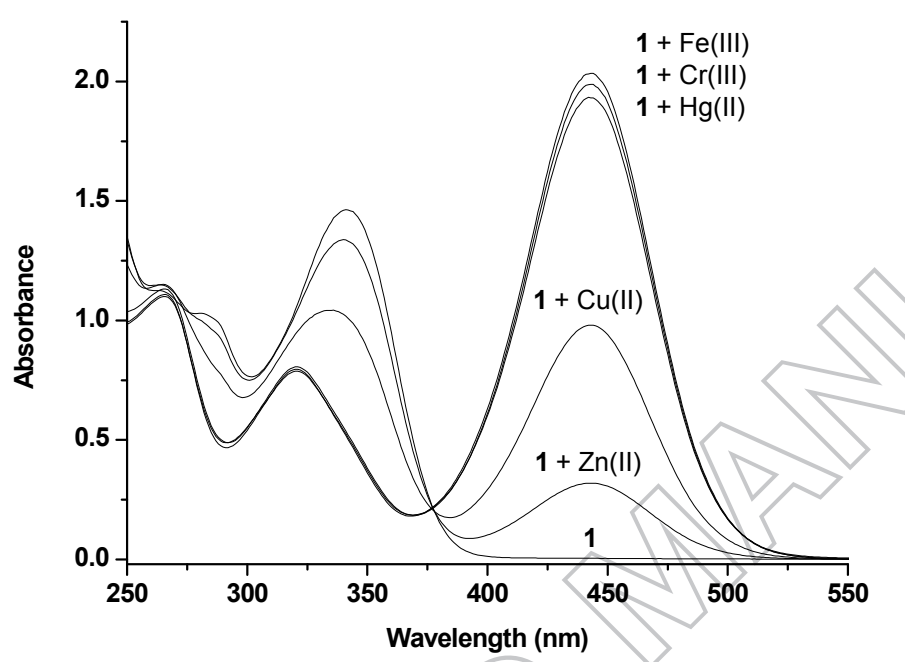

b)

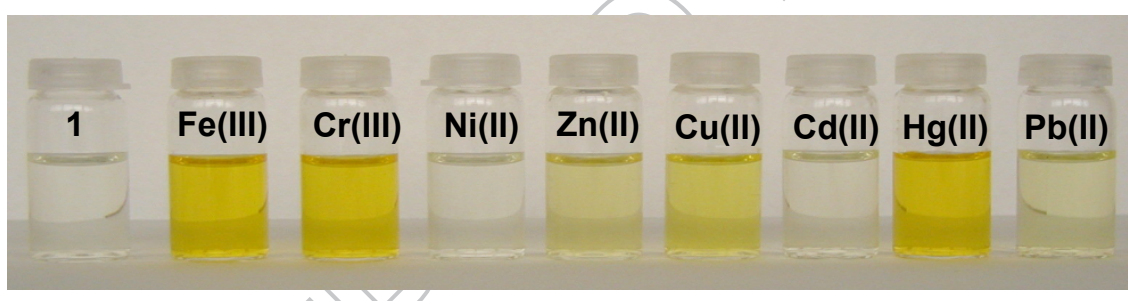

Figure 1. a) UV-visible spectra of probe $1\left(9.0 \times 10^{-5} \mathrm{M}\right.$ in acetonitrile) alone and in the presence of one eq. of selected metal cations. b) Color changes observed upon addition of one eq. of selected metal cations to acetonitrile solutions of probe $1\left(9.0 \times 10^{-5} \mathrm{M}\right)$. 


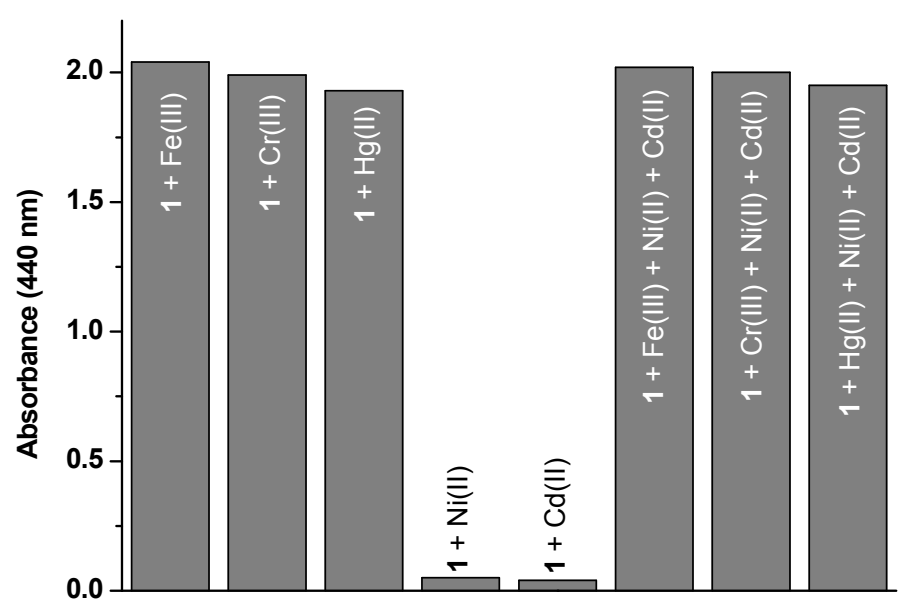

Figure 2. Absorbance at $440 \mathrm{~nm}$ of acetonitrile solutions of probe $1\left(9.0 \times 10^{-5} \mathrm{M}\right)$ in the presence of one eq. of selected metal cations.

a)

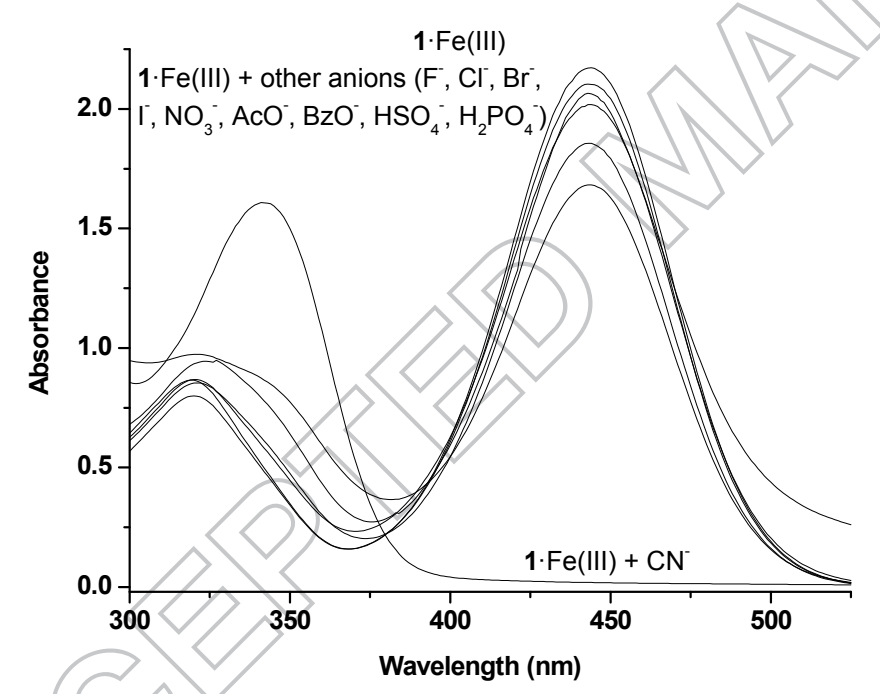

b)

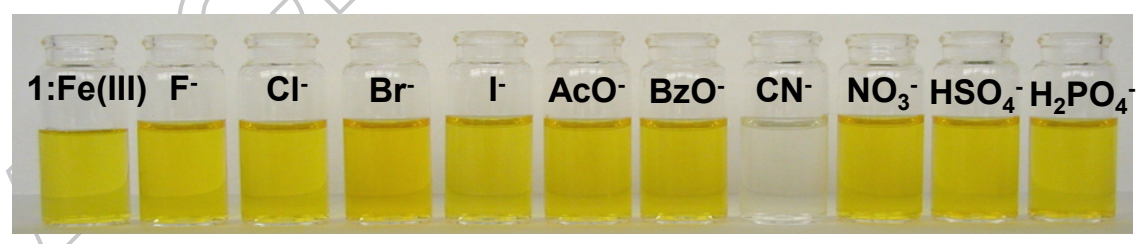

Figure 3. a) UV-visible spectra of complex $1 \cdot \mathrm{Fe}(\mathrm{III})\left(9.0 \times 10^{-5} \mathrm{M}\right.$ in acetonitrile $)$ alone and in the presence of one eq. of selected anions. b) Color changes observed upon addition of one eq. of selected anions to acetonitrile solutions of complex $1 \cdot \mathrm{Fe}(\mathrm{III})\left(9.0 \times 10^{-5} \mathrm{M}\right)$. 


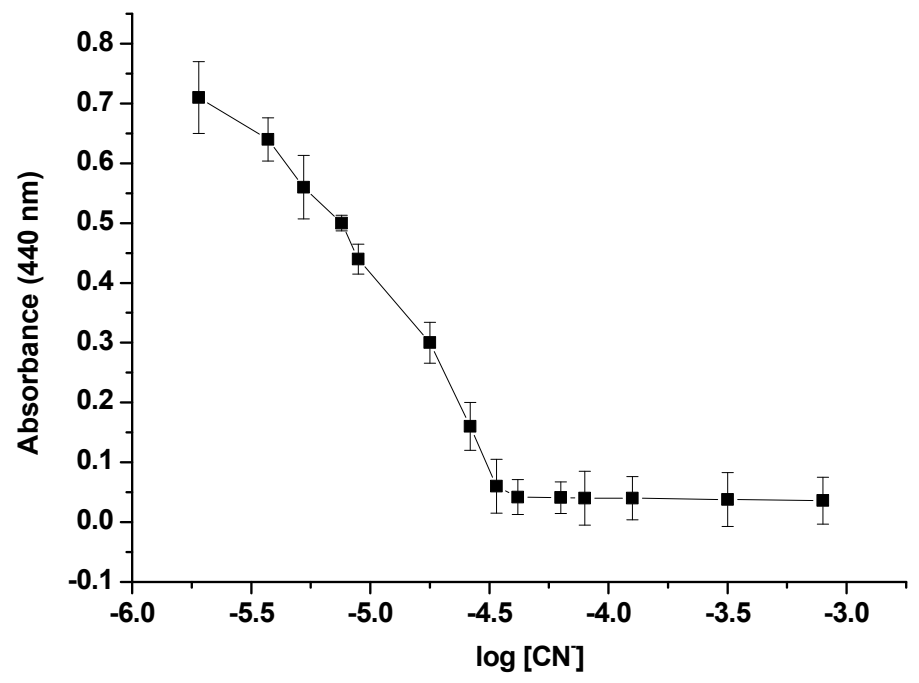

Figure 4. Absorbance at $440 \mathrm{~nm}$ for $\mathbf{1} \cdot \mathrm{Fe}$ (III) complex $\left(1.0 \times 10^{-4} \mathrm{M}\right)$ in acetonitrile-water 90:10 v/v mixture upon addition of increasing quantities of cyanide.

\section{Graphical abstract}
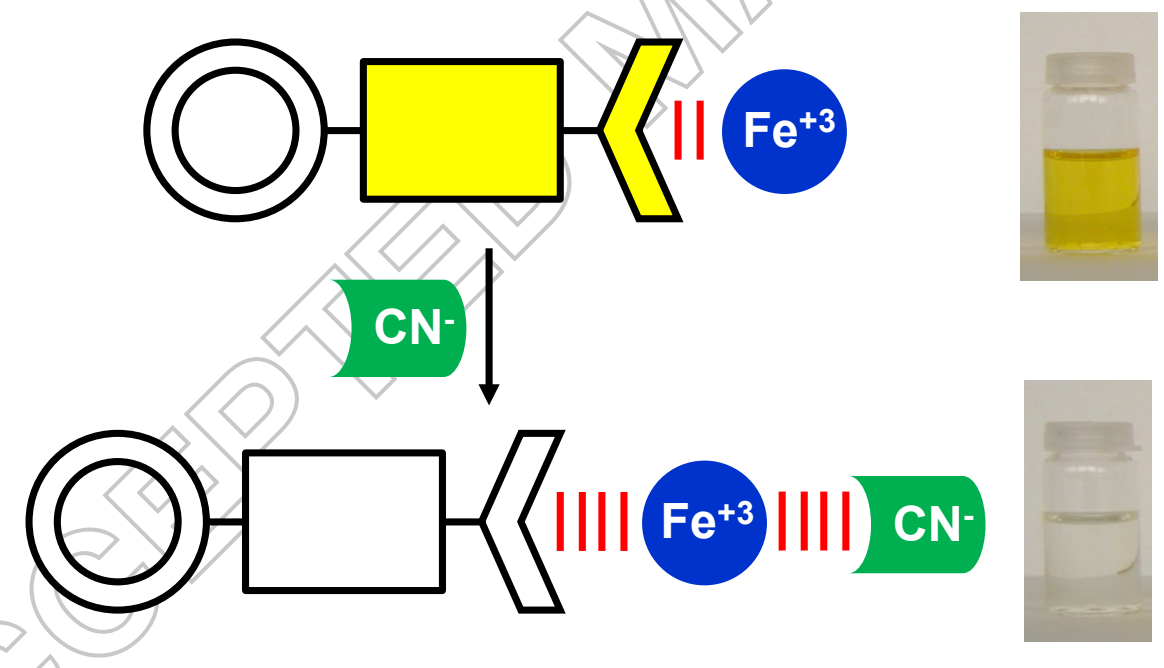